\title{
Heavy metal assessment of polluted soil around Hatirjheel Lake of Dhaka city, Bangladesh
}

\author{
M. A. Hashem ${ }^{1 *}$, M. S. Nur-A-Tomal' ${ }^{1}$, M. J. Abedin² and S. A. Bushra1 \\ ${ }^{1}$ Department of Leather Engineering, Khulna University of Engineering \& Technology (KUET), Khulna-9203, Bangladesh \\ ${ }^{2}$ Department of Chemistry, Jagannath University, Dhaka-1100, Bangladesh
}

\begin{abstract}
Heavy metals contamination in soil is a big issue to the environment because of its potential risk to the ecosystem and human health. Industrialization increases the disposal of industrial wastes containing heavy metals. Most industries are located near the bank of rivers or Lakes where industries can dump their effluents without proper treatment. In this study, an investigation was carried out to evaluate the heavy metals of the contaminated soil near Hatirjheel Lake of Dhaka city, Bangladesh. The collected soil samples were air-dried, acid digested and aliquots were analyzed by the atomic absorption spectroscopy for the quantification of heavy metals. The ranges of heavy metals were found in soil: arsenic $2.7-33.3 \mathrm{mg} / \mathrm{kg}$, lead $9.5-74.9 \mathrm{mg} / \mathrm{kg}$, chromium $21.8-43.1 \mathrm{mg} / \mathrm{kg}$, manganese $138.3-222.7 \mathrm{mg} / \mathrm{kg}$ and iron $159032.9-246382.8 \mathrm{mg} / \mathrm{kg}$, respectively. Cadmium was below the detection limit. The dominance of heavy metals series in the soil follows: $\mathrm{Fe}>\mathrm{Mn}>\mathrm{Cr}>\mathrm{Pb}>\mathrm{As}>\mathrm{Cd}$. Heavy metals content in the soil by comparison with the USEPA guidelines show that $\mathrm{Pb}$ was nonpolluted; $\mathrm{Cr}$ and $\mathrm{Mn}$ were moderately polluted; As and Fe were heavily polluted in the study area. Heavy metals accumulation in the soil could pose a potential risk to the ecosystem as well as to human health.
\end{abstract}

Key words: Soil; Heavy metals; Environment; Hatirjheel Lake; Dhaka

\section{Introduction}

Bangladesh is a developing country where rapid industrialization is the most common because of having low-cost labor and availability of raw materials. Unfortunately, the industries are establishing without any proper planning and regulations. Increasing industrialization, disposal of industrial waste is also increased (Jacob and Otte, 2004; Stoltz and Greger, 2006; Ettler et al., 2004; Carbonell-Barrachina, 1999). Most of the industries are located near/on the bank of rivers or lakes where industries dump effluents directly without proper treatment. Consequently, industries are creating environmental pollution, especially water pollution and also in consequence soil and air pollution. The impact of rapid industrialization on the environment is threatening both the existing nature as well as for the forthcoming generation.

In the last few decades, environmental pollution due to toxic heavy metals has gained attention. During the manufacturing process, it consumes a huge amount of natural and synthetic chemicals, which mainly based on heavy metals. Sediment, soil and water contamination with heavy metals is a big threat to the environment because of its various harmful effects on human and other animals (Patra et al., 2007). Anthropogenic sources e, g, vehicular exhaust and industrial activities are the major sources of soil contamination with heavy metals. Due to increasing industrialization, disposing of industrial waste, mine tailings, metallurgical slags and municipal sewage sludge are also increased. Hereafter, soil is contaminated from where possibilities of leaching toxic heavy metals into the ground water/surface water or entering the human food chain through various chemical and biological reactions. Metal contaminated vegetables ingesting is one of the most important conduits for metal exposure to human (Sipter et al., 2008). Of course, a small amount of heavy metals is beneficial for the metabolism of human body and beyond that limit is hazardous to human body and can cause different diseases (AACAP, 2012). The accumulation of heavy metals in the soil also adversely affects its physicochemical properties leading to infertility and low yield of crops (Khan et al., 2009). Contamination of ground water by the heavy metals may pose a more serious and continuing health risk to human as well as to the environment (Bhagure and Mirgane, 2011).

Hatirjheel is one of the polluting Lakes situated in Dhaka metropolitan which is surrounded by Tejgaon, Gulshan, Badda, Rampura, Niketon, Maghbazar, etc. Various 
industries like textiles, polycon, battery and paint, etc. are established around the Lake and most of them are textiles. During the textile manufacturing process, it consumes a huge amount of water, dyestuffs and synthetic chemicals, which are mainly based on heavy metals. Waste water from the textile requires a complicated treatment process like physicochemical or biological treatment due to containing a high concentration of pollutants, complex composition and high concentration of dyes. It is a matter of distress that most of the industries have not installed waste treatment plant to minimize the overall production cost. The Lake is polluted by the industrial activities, i.e. discharging of industrial effluents directly or indirectly, without proper treatment, which contains a considerable amount of heavy metals. As per the policy of Government of the People's Republic of Bangladesh, the Hatirjheel Lake was cleaned in 2012-2013, but still the impact of previously introduced heavy metals is continuing. The purpose of this study is to know the current condition of Hatirjheel Lake.

In this study, an investigation has been attempted to determine the heavy metal content in soil near Hatirjheel Lake at different points. The collected soil samples were acid digested and aliquots were analyzed by the atomic absorption spectroscopy for the quantification of arsenic $(\mathrm{As})$, chromium $(\mathrm{Cr})$, cadmium $(\mathrm{Cd})$, Iron $(\mathrm{Fe})$, lead $(\mathrm{Pb})$ and manganese $(\mathrm{Mn})$.

\section{Materials and methods}

Study area

Dhaka is the capital city of Bangladesh, which is one of the most densely populated cities in the world. The Hatirjheel Lake is located at the center of Dhaka city, which is considered as the largest water body in the Dhaka city. Tejgaon industrial area is located near Hatirjheel Lake

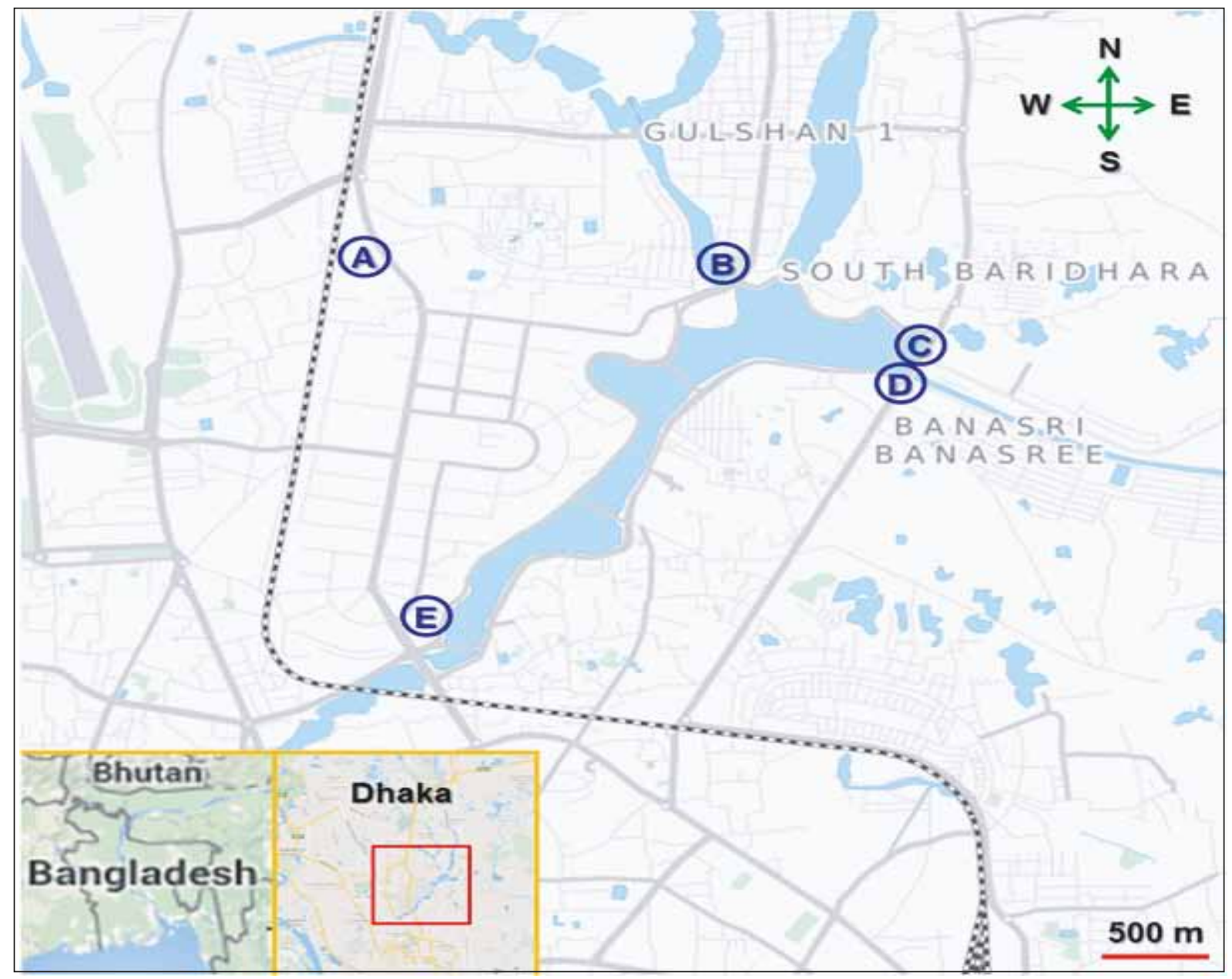

Fig. 1. Sampling locations near Hatirjheel Lake, Dhaka. 
which is one of the largest industrial are as consisting a numbers of local and a foreign industry e.g. garments, footwear, plastics, paints and batteries. Effluents of those industries are discharged without any treatment through the open drain adjacent to the Hatirjheel area. In this investigation, soil samples were collected from the five locations of Hatirjheel Lake to assess the pollution level of heavy metals, which is indicated in Fig. 1. The sampling points were: A) near Jamuna garments, B) joint place of Hatirjheel and Gulshan Lake, C) near Rampura bridge (north side), D) near rampura bridge (south side) and E) near Hatirjheel first bridge.

\section{Sampling}

The soil samples were collected at a depth of $30 \mathrm{~cm}$ from the existing ground surfaceat area $20 \mathrm{~cm} \times 20 \mathrm{~cm} \times 5 \mathrm{~cm}$ $(\mathrm{L} \times \mathrm{W} \times \mathrm{H})$ from the five points of the Hatirjheel Lake in a polyethylene bag and brought back to the laboratory. The soil samples were air-dried, grinded with a mortar and sieved with 80-mesh. After sieving, the soil samples were homogeneously mixed for the next processing.

\section{Reagents}

All the stock solutions were prepared from the analytical grade. The soil sample was acid digested with nitric acid (Merck KGaA, Germany) and hydrogen peroxide (Merck, India) which was collected from the local scientific store. Freshly prepared double deionized water was used in the all experiments. Chromium $(\mathrm{Cr})$, arsenic $(\mathrm{As})$, lead $(\mathrm{Pb})$, manganese $(\mathrm{Mn})$ and cadmium $(\mathrm{Cd})$ standard solution were obtained from the Fluka-Analytical, Switzerland. To reduce $\mathrm{As}(\mathrm{V})$ to $\mathrm{As}(\mathrm{III}), 20 \%$ potassium iodide (Sigma-Aldrich, USA) solution was used. Arsenic trihydride $\left(\mathrm{AsH}_{3}\right)$ generation was performed with $5 \mathrm{M}$ hydrochloric acid (Sigma-Aldrich, USA) and $0.6 \%$ sodium borohydride solution (Sigma-Aldrich, USA).

\section{Physicochemical properties of soil}

The $\mathrm{pH}, \mathrm{EC}$ and texture of the soil were measured. The soil/deionized water was mixed (1:2.5) and stirred with a glass rod and allowed to equilibrate for $30 \mathrm{~min}$. The $\mathrm{pH}$ was measured using a pH meter (UPH-314, USA). To measure electrical conductivity (EC), $5 \mathrm{~g}$ soil sample was taken in 50 $\mathrm{mL}$ polypropylene tube and $30 \mathrm{~mL}$ deionized water was added to the tube. Properly, lid was closed and tube was shaken for 5 minutes. The EC was used using the EC meter (CT-67, USA). Before measuring $\mathrm{pH}$ and EC, both the meters were calibrated with the standard solutions. The particle size distribution of the soil was determined using hydrometer and classified according to the USDA soil classification system(USDA 1987).

\section{Acid digestion}

Homogeneously mixed soil samples were acid digested following the EPA Method 3050B (USEPA, 1996). Each soil sample $(2.0 \mathrm{~g})$ was acid digested with nitric acid. The acid mixed soil samples were heated, refluxed on a hot plate for several hours and occasionally nitric acid was added until no brown fumes were given off. Then, the mixture was cooled and hydrogen peroxide was added. The mixture was then heated, refluxed on a hot plate and hydrogen peroxide was added until the effervescence was minimal or the mixture appearance was unchanged. The mixture was heated continuing until the volume had become $5 \mathrm{~mL}$. Then, $50 \mathrm{~mL}$ deionized water was added and again heated for another one hour. The mixture was then cooled, filtered through the filter paper (Whatman No.1) and the solution was made up $100 \mathrm{~mL}$ with deionized water. The filtrate (aliquot) was preserved in a high-density polyethylene (HDPE) bottle at $4^{\circ} \mathrm{C}$ until to complete metals analysis.

Analysis of heavy metals with AAS

Acid digested aliquot was analyzed by the atomic absorption spectroscopy (SpectrAA-220, VARIAN, Australia) for the quantitative measurement of $\mathrm{Cr}, \mathrm{As}, \mathrm{Pb}$, $\mathrm{Fe}, \mathrm{Mn}$ and $\mathrm{Cd}$. Arsenic was measured by the hydride vapor generation method using sodium borohydride as a reducing agent, argon (Ar) as carrier gas at the wavelength of 193.7 $\mathrm{nm}$. $\mathrm{Cr}, \mathrm{Pb}, \mathrm{Fe}, \mathrm{Mn}$ and $\mathrm{Cd}$ were measured direct flame (airacetylene) at the wavelength of $357.9 \mathrm{~nm}, 217.0 \mathrm{~nm}$, $248.3 \mathrm{~nm}, 279.5 \mathrm{~nm}$ and $228.8 \mathrm{~nm}$, respectively. Triplicate measurement was conducted for each metal.

\section{Results and discussion}

Proper ties of soil

Fig. 2 shows the prepared soil samples. The results of physicochemical analysis are inserted in Table 1 . The $\mathrm{pH}$ level of the soil samples was 7.11-7.81. It seems that the soil was slightly alkaline. The EC values of soil samples were ranged 268.2-1658.0 $\mu \mathrm{S} / \mathrm{cm}$. According to the USDA (1987) textural analysis, soil samples were classified as: fine sand, sandy loam, sandy clay loam, and silt loam class.

\section{Heavy metals content in soil}

The results of AAS analysis shows the various concentrations of $\mathrm{Cr}, \mathrm{As}, \mathrm{Pb}, \mathrm{Mn}$ and $\mathrm{Cd}$ in the soil samples are inserted in Table I. The ranges of heavy metals were contained in the soil: $\mathrm{Cr} 21.8-43.1 \mathrm{mg} / \mathrm{kg}, \mathrm{Pb} 9.5-74.9$ $\mathrm{mg} / \mathrm{kg}$, As $2.7-33.3 \mathrm{mg} / \mathrm{kg}$, and $\mathrm{Mn} 138.3-222.7 \mathrm{mg} / \mathrm{kg}$. The amount of $\mathrm{Cd}$ was in the soil below the detection limit. Among the various concentrations of heavy metals, $\mathrm{Fe}$ was at a higher level. The presence of heavy metals follows the series: $\mathrm{Fe}>\mathrm{Mn}>\mathrm{Cr}>\mathrm{Pb}>\mathrm{As}>\mathrm{Cd}$. Assessing the environmental condition of heavy metals in soil by comparison with the US Environmental Protection Agency (USEPA) guidelines (Table I) show that $\mathrm{Pb}$ element is nonpolluted; $\mathrm{Cr}$ and $\mathrm{Mn}$ elements are moderately polluted; As, and $\mathrm{Fe}$ elements are heavily polluted in this study area. 

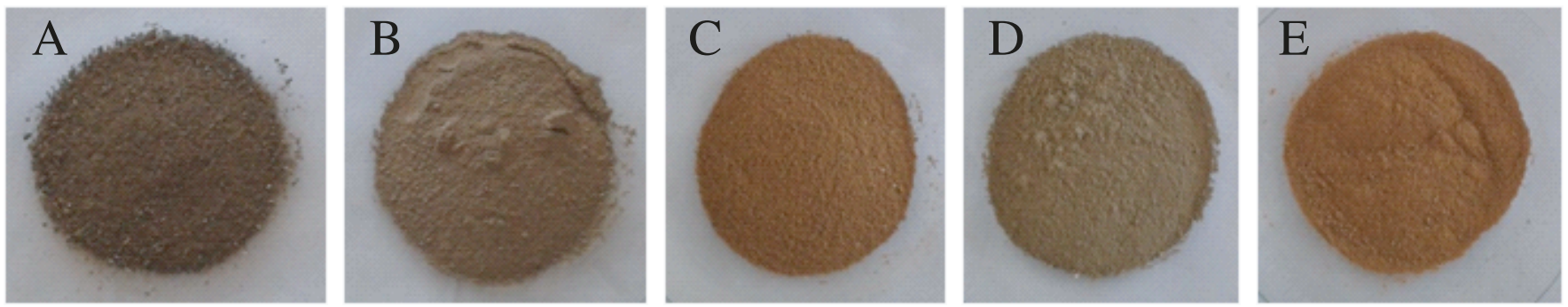

Fig. 2. Physical appearance of the soil samples.

The industries are located in the investigated area; they use various types of metals incorporate with different chemicals. After processing, metal wastes are discharged from the industries in the wastewater stream. Finally, it falls into the Hatirjheel Lake. It may be the reason to contaminate the soil with heavy metals near Hatirjheel area. The most commonly used metals in dyestuffs production are $\mathrm{Cr}$. However, the source of As is from the source of reagents or chemicals used in the textile process.
Leaching of heavy metals from the soil

Many factors are responsible for leaching of heavy metals from the sediment/soil. $\mathrm{pH}$ is one of the most important factors for the leaching of heavy metals from the sediment/soil into ground water. At low $\mathrm{pH}$, the solubility of $\mathrm{Pb}$ and $\mathrm{Cd}$ are increased, whereas $\mathrm{Cr}$ and As form different compound or complexes at different $\mathrm{pH}$. Higher the $\mathrm{pH}$, the solubility of $\mathrm{Cr}(\mathrm{VI})$ and $\mathrm{As}(\mathrm{III})$ are increased. The mobility of As(III) compounds is 4-10 times higher than the As(V)

Table I. Physicochemical properties of the soil samples near Hatirjheel Lake

\begin{tabular}{|c|c|c|c|c|c|c|c|}
\hline ID & $\mathrm{pH}$ & $\underset{(\mu \mathrm{S} / \mathrm{cm})}{\mathrm{EC}}$ & $\begin{array}{c}\text { Sand }(\%) \\
(2.0-0.05 \mathrm{~mm})\end{array}$ & \multicolumn{2}{|c|}{$\begin{array}{c}\text { Silt }(\%) \\
(0.05-0.002 \mathrm{~mm})\end{array}$} & $\begin{array}{c}\text { Clay }(\%) \\
(<0.002 \mathrm{~mm})\end{array}$ & Color \\
\hline $\mathrm{A}$ & 7.11 & 1658 & 57.67 & 30.74 & 11.59 & Sandy loam & Dark brown \\
\hline $\mathrm{B}$ & 7.68 & 439.7 & 29.93 & 61.00 & 9.07 & Silt loam & Reddish grey \\
\hline $\mathrm{C}$ & 7.79 & 282.8 & 87.89 & 11.86 & 0.25 & Fine sand & Red brown \\
\hline $\mathrm{D}$ & 7.81 & 268.2 & 60.23 & 38.26 & 1.51 & Sandy loam & Light grey \\
\hline $\mathrm{E}$ & 7.69 & 415.9 & 56.40 & 29.49 & 14.11 & Sandy clay loam & Red brown \\
\hline
\end{tabular}

Table II. Heavy metals content in the soil and comparison with USEPA (1977) guidelines for sediments

\begin{tabular}{|c|c|c|c|c|c|c|}
\hline \multirow{2}{*}{\multicolumn{2}{|c|}{ ID/Guideline }} & \multicolumn{5}{|c|}{ Heavy metal (mg/kg) } \\
\hline & & As & $\mathrm{Cr}$ & $\mathrm{Fe}$ & $\mathrm{Mn}$ & $\mathrm{Pb}$ \\
\hline \multicolumn{2}{|l|}{ A } & $2.71 \pm 0.12$ & $43.14 \pm 0.59$ & $163369.28 \pm 10.03$ & $141.04 \pm 0.69$ & $75.54 \pm 0.71$ \\
\hline \multicolumn{2}{|l|}{$\mathrm{B}$} & $33.30 \pm 0.34$ & $33.29 \pm 0.46$ & $193556.53 \pm 12.38$ & $138.30 \pm 0.81$ & $31.87 \pm 0.39$ \\
\hline \multicolumn{2}{|l|}{$\mathrm{C}$} & $21.82 \pm 0.28$ & $21.82 \pm 0.29$ & $159032.92 \pm 9.25$ & $218.19 \pm 1.02$ & $12.02 \pm 0.23$ \\
\hline \multicolumn{2}{|l|}{$\mathrm{D}$} & $32.74 \pm 0.49$ & $32.74 \pm 0.40$ & $246382.80 \pm 14.82$ & $221.00 \pm 1.15$ & $18.24 \pm 0.40$ \\
\hline \multicolumn{2}{|l|}{$\mathrm{E}$} & $25.20 \pm 0.36$ & $25.20 \pm 0.35$ & $234410.84 \pm 17.27$ & $222.70 \pm 0.98$ & $10.92 \pm 0.18$ \\
\hline \multirow{3}{*}{ 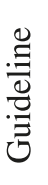 } & Nonpolluted & $<3$ & $<25$ & $<17000$ & $<300$ & $<40$ \\
\hline & Moderately polluted & $3-8$ & $25-75$ & $17000-25000$ & $300-500$ & $40-60$ \\
\hline & Heavily polluted & $>8$ & $>75$ & $>25000$ & $>500$ & $40-60$ \\
\hline
\end{tabular}


compounds (McLean and Bledsoe, 1992). $\mathrm{Cr}(\mathrm{III})$ and As(V) are the least mobile. Soluble and un-adsorbed chromium complexes can leach from the sediment/soil into ground water. If the $\mathrm{pH}$ changes for any causes, it will be horrible for our mankind as well as for the ecology. Other different factors, e.g. temperature, amount of organic matter in the soil, residual time of the sludge and soil texture and pore structure play an important role in leaching the heavy metals (Sherene, 2010).

\section{Potential risk of $\mathrm{Cr}, \mathrm{As}, \mathrm{Pb}, \mathrm{Mn}$ and $\mathrm{Cd}$}

Chromium is associated with allergic dermatitis in human health (Sherene, 2010). $\mathrm{Cr}$ (III) has a toxic effect upon daphnia, thus disrupting the food chain for fish life and possibly inhibiting the photosynthesis even in low concentration. Dichromate is toxic to fish life since they swiftly penetrate into the cell wall.

Arsenic compounds are adsorbed strongly to sediment/soil. It transports only over short distances into groundwater as well as surface water. It is associated with skin damage, increased risk of cancer, and problems with the circulatory system (Scragg, 2006). Children expose to arsenic show impaired learning and memory, sleep disturbances, abnormality and hearing problem (Yadav et al., 2011). Patients who are exposed to arsenic may disorder of the brain, impairments of higher neurological functions including learning, memory, and attentiveness (Rodriguez et al., 2003).

Inhalation and ingestion are the two routes of $\mathrm{Pb}$ exposure and effects from the both are same. $\mathrm{Pb}$ accumulates in the body organs (brain), which may lead to poisoning or even death. Children exposed to $\mathrm{Pb}$ are at risk for impaired development: lower IQ, shortened attention span, hyperactivity, and mental deterioration, etc.; children under the age of six are at more substantial risk. Cadmium is a poisonous metal and it is very bio-persistent but has few toxicological properties (Järup, 2003).

\section{Conclusion}

The study reveals that the soil was contaminated with iron, manganese, chromium, arsenic and lead. The cadmium was too low that was below the detection limit. The waste water from the industries is discharged without accomplishing any recovery/reuse system, which is rich of heavy metals. The discharged wastewater containing heavy metals increased the heavy metals content in sediment/soil of the adjacent area of Hatirjheel Lake. The heavy metals may leach from the sediment/soil to groundwater in the near future that could be a great threat to human. It could be better to develop a process to recovery the heavy metals from the waste water and sludge so that it could save the environment.

\section{References}

American Academy of Child \& Adolescent Psychiatry (AACAP) (2012), Lead exposure in children affects brain and behavior, facts for families.

Bhagure GR and Mirgane SR (2011), Heavy metal concentrations in groundwaters and soils of Thane Region of Maharashtra, India. Environ, Monit.Assess. 173: 643-652.

Carbonell-Barrachina AA, Jugsujinda A, Burlo, F Delaune, RD and Patrick JRWH. (1999), Arsenic chemistry in municipal sewage sludge as affected by redox potential and $\mathrm{pH}$, Water Res. 34: 216-224.

Ettler V, Komarkova M, Jehlicka J, Coufal, Hradil, PD, Machovic V and Delorme F (2004), Leaching of lead metallurgical slag in citric solutions-implications for disposal and weathering in soil environments, Chemosphere 75: 567-577.

Jacob DL and Otte ML (2004), Influence of Typhalatifolia and fertilization on metal mobility in two different $\mathrm{Pb}-\mathrm{Zn}$ mine tailings types, Sci. Total Environ. 333: 924.

Järup L (2003), Hazards of heavy metal contamination, $B r$. Med. Bull. 68: 167-182.

Khan MS, Zaidi A, Wani PA and Oves M (2009), Role of Plant Growth Promoting Rhizobacteria in the Remediation of Metal Contaminated Soils. Environ. Chem. Lett. 7: 1-19.

McLean JE and Bledsoe BE (1992), Ground Water Issue, Behavior of Metals in Soils. United States Environmental Protection Agency.

Patra RC, Swarup D, Naresh R, Kumar P, Nandi D, Shekhar P, Roy S and Ali SL (2007), Tail hair as an indicator of environmental exposure of cows to lead and cadmium in different industrial areas, Ecotox Environ Safe 66: 27-131.

Rodriguez VM, Capdeville MEJ and Giordano M (2003), The effects of arsenic exposure on the nervous system, ToxicolLett. 145: 1-18.

Scragg A (2006), Environmental Biotechnology, Oxford University Press, Oxford.

Sherene T (2010), Mobility and transport of heavy metals in polluted soil environment. Biological Forum-An International Journal 2: 112-121.

Sipter E, Rózsa E, Gruiz K, Tátrai E and Morvai V (2008), Site-specific risk assessment in contaminated vegetable gardens, Chemosphere 71: 1301-1307. 
Stoltz E and Greger M (2006), Release of metals and arsenic from various mine tailings by Eriophorum angustifolium, Plant Soil 289: 199-210.

USDA (1987), USDA textural soil classification.

USEPA (1996), Acid digestion of sediments, sludges, and soils.

USEPA (1977), Guidelines for the pollutional classification of great lakes harbor sediments. US Environmental Protection Agency, Region V, April 1977.
Yadav RS, Chandravanshi LP, Shukla RK, Sankhwar ML, Ansari RW, Shukla, PK, Pant, AB and Khanna VK (2011), Neuroprotective efficacy of curcumin in arsenic induced cholinergic dysfunctions in rats, NeuroToxicology 32: 760-768.

Received: 18 April 2016; Revised: 26 July 2016; Accepted: 28 July 2016. 